\title{
REPRESENTASI POST POWER SYNDROME DALAM FILM ANIMASI GOLDEN TIME (2014) KARYA TAKUYA INABA
}

\author{
N.P.Rasmi ${ }^{1}$, I.W. Sadyana ${ }^{2}$,G.S.Hermawan ${ }^{3}$ \\ Prodi Pendidikan Bahasa Jepang \\ Universitas Pendidikan Ganesha \\ Singaraja \\ e-mail: rasmiparamita@gmail.com \\ wayan.sadyana@undiksha.ac.id satya.hermawan@undiksha.ac.id
}

\begin{abstract}
ABSTRAK
Penelitian ini bertujuan untuk mendeskripsikan representasi visual yang menunjukkan post power syndrome pada film Golden Time (2014) karya Takuya Inaba. Penelitian ini merupakan penelitian deskriptif kualitatif. Teknik analisis data yang digunakan dalam penelitian ini adalah teknik analisis mengalir. Objek penelitian ini adalah tanda-tanda yang menunjukkan post power syndrome. Hasil penelitian ini menunjukkan bahwa ada 4 tanda yang menunjukkkan makna denotasi. Tanda yang ditemukan yaitu tanda yang menunjukkan sikap berkuasa, tanda yang menunjukkan penolakan situasi baru, tanda yang menunjukkan rasa tidak percaya diri, dan tanda yang menunjukkan optimisme. Makna konotasi menunjuk kepada transisi perekonomian Jepang dari tahun 1950-an hingga 1980-an. Transisi ini secara mitos digunakan untuk menunjukan optimisme Jepang dalam mentransformasi posisinya di dunia, baik itu dalam bidang industri, politik, maupun ekonomi.
\end{abstract}

Kata kunci: Post power syndrome, representasi, sang tv tua

$$
\begin{aligned}
& \text { ゴールデンタイムフィルムの卓也稲葉様にポストパワー症候群の表現について } \\
& \text { ニ・ニョマン・パラミタ・ラスミ } \\
& \text { 日本語教育学科 } \\
& \text { 要旨 }
\end{aligned}
$$

本研究の目的はゴールデンタイムフィルム「2014」の稲葉卓也にポストパワー症候群を 示寸視覚的表現を説明する。本研究は定性的記述法である。データは流れる分析手法に より分析した。対象はポストパワー症候群を示す象徵である。結果は表示の意味を示す 象徴が 4 つである。4 象徵は権威 を示寸象徵である。新しい状況の拒絶を示寸象徴であ る。自信がないことを示す象徴である。楽観主義を示寸象徴である。含意の意味は 1950 年代から 1980 年代への日本の経済移行を示す。この移行は、産業、政治、経済の両方 の分野で世界における日本の地位を変える楽観的な見方を示寸神話である。

キーワード：ポストパワー症候群、表現、象徴

\section{PENDAHULUAN}

Post-Power Syndrome dialami terutama orang yang sudah lanjut usia dan pensiun dari pekerjaannya. Hanya saja banyak orang yang berhasil melalui fase ini dengan cepat dan dapat menerima kenyataan dengan hati yang lapang. Tetapi pada kasus-kasus tertentu, dimana seseorang tidak mampu menerima kenyataan yang ada, ditambah dengan tuntunan hidup yang terus mendesak, dan dirinya adalah satu-satunya penopang hidup keluarga, resiko terjadinya Post Power Syndrome semakin besar, Elia (2003 dalam Suyanto, 2016). 
Keadaan ini direpresentasikan dengan menarik oleh Takuya Inaba melalui animasi pendek berjudul Golden Times (2014). Golden times mengisahkan tentang sebuah televisi yang diproduksi pada tahun 1960-an dibuang di tempat pembuangan. Film ini bersetting tahun 1980-an. Sang televisi tua ini tidak bisa menerima dirinya ketika ia dibuang. la merasa masih bisa berfungsi. Di tempat pembuangan itu ia berusaha untuk keluar, dan menunjukan jati dirinya. Pada akhirnya san televisi tua tersebut berakhir sebagai kandang ayam di sebuah rumah peternakan. Akhir cerita ini merepresentasikan cara menempatkan diri ketika sebuah masa kejayaan itu telah berakhir.

Berdasarkan latar belakang, maka penelitian ini akan mendeskripsikan tentang tentang representasi post-power syndrome dalam dalam film animasi Golden Time (2014) karya Takuya Inaba. Pendekatan yang dipergunakan adalah pendekatan semiotika milik Roland Barthes.Teori yang digunakan dalam penelitian ini adalah teori semiotika dari barthes. Yaitu teori denotasi dan konotasi. Denotasi merupakan sistem signifikansi tingkat pertama. Denotasi makna kamus dari sebuah kata atau terminologi atau objek literal meaning of a term or object). Makna denotasi bersifat langsung, yaitu makna khusus yang terdapat dalam sebuah tanda dan pada intinya dapat disebut sebagai gambaran sebuah pertanda. Konotasi mempunyai makna yang subjektif atau paling tidak intersubjektif sehingga kehadirannya tidak disadari makna konotasi disisi lain mengacu pada sesusatu yang masih kurang pasti dan oleh karenanya maknanya bisa berubah, dikonvensionalisasikan dan bersifat asosiatif.

Rumusan masalah yang ingin diteliti dalam penelitian ini adalah bagaimana representasi post- power syndrome pada film Golden Time 2014 karya Takuya Inaba? Rancangan penelitian deskripti kualitatif digunakan untuk mendeskripsikan representasi post-power syndrome dari tokoh utama pada film Golden Time (2014) karya Takuya Inaba. Data yang didapat setelah menonton film tersebut, berupa sebuah deskripsi terhadap tanda-tanda visual yang menunjukan post-power syndrome. Kemudian dipaparkan melalui tulisan sesuai dengan karakteristik dari penelitian deskriptif kualitatif. Tujuan yang ingin dicapai peneliti dalam penelitian ini adalah untuk mendeskripsikan representasi visual yang menunjukan post-power syndrome pada film Golden Time (2014) karya Takuya Inaba.

\section{METODE}

Dalam penelitian ini menggunakan rancangan penelitian deskriptif kualitatif. Penelitian deskriptif kualitatif adalah suatu penelitian yang dilakukan untuk menggambarkan, menjabarkan suatu fenomena saat ini, dengan menggunakan prosedur ilmiah untuk menjawab suatu permasalahan secara tepat dan akurat (Redana, 2006). Penelitian kualitatif adalah penelitian yang menggunakan uraian kata-kata untuk mendeskripsikan data yang diperoleh. Rancangan penelitian deskripti kualitatif digunakan untuk mendeskripsikan representasi postpower syndrome dari tokoh utama pada film Golden Time (2014) karya Takuya Inaba. Data yang didapat setelah menonton film tersebut, berupa sebuah deskripsi terhadap tanda-tanda visual yang menunjukan post-power syndrome. Kemudian dipaparkan melalui tulisan sesuai dengan karakteristik dari penelitian deskriptif kualitatif.

Teknik yang digunakan dalam pengumpulan data dalam penelitian ini adalah studi pustaka (library research), yaitu dengan cara mencatat dokumen atau arsip yang berkaitan dengan penelitian yang dilakukan. Langkah-langkah yang dilakukan dalam penelitian ini adalah sebagai berikut.Menonton film Golden 
Time (2014), menangkap layar dari cuplikan film yang menunjukan tanda-tanda visual post-power syndrome,mencatat serta mengumpulkan teori yang relevan dengan penelitian, melakukan analisis penelitian berdasarkan teori yang sudah ada, lalu menarik simpulan. Data yang didapat kemudian dianalisis menggunakan teknik analisis mengalir. Dalam teknik analisis mengalir terdiri dari tiga alur kegiatan yang terjadi secara bersamaan, yaitu reduksi data merupakan bagian dari analisis, suatu bentuk analisis yang memperjelas, memperpendek, terfokus, memilah data penting, dan mengatur data sedemikian rupa, sehingga kesimpulan akhir dapat dilakukan., penyajian data dalam alur penyajian data, dilakukan suatu pengumpulan data atau informasi yang akan membantu penelitian untuk mengetahui suatu kemungkinan untuk mengerjakan suatu tindakan atau analisis lain berdasarkan penelitian tersebut. dan penarikan simpulan Dari data yang didapat dari penyajian data, maka proses memasuki penarikan simpulan. Simpulan akhir tidak akan tercapai sampai proses pengumpulan data berakhir.. Tiga alur kegiatan ini terjadi secara bersamaan dan saling menjalin, baik sebelum, selama, dan sesudah pengumpulan data secara pararel (Miles and Huberman, 1994: 13).

\section{HASIL DAN PEMBAHASAN}

Hasil penelitian ini ditemukan ada empat tanda visual yang bermakna denotasi. Makna denotasi ini nantinya akan dianalisis lebih lanjut untuk mengetahui makna konotasi atau makna lapisan kedua dari tanda tersebut. Hasil yang ditemukan yaitu.

1. Tanda yang menunjukan sikap berkuasa.

Tanda ini terlihat pada awal-awal film. Sang televisi tua ketika pertama kali diturunkan dari mobil dan diletakan di tempat pembuangan, dirinya masih merasa memiliki kekuasaan atau hal dibanggakan. Tanda ini secara jelas terlihat, ketika boneka kelinci mekanik.menyambungkan kabel televisi dan mencari saluran televisi, reaksi dari sang televisi tua jutru mencabut stop kontak dan mengusir boneka kelinci mekanik.

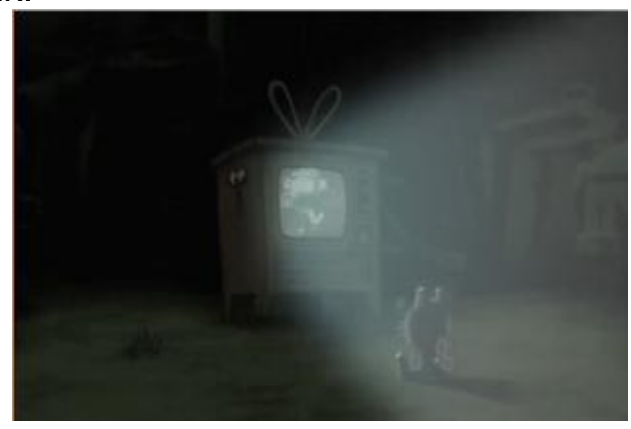

Gambar 1. Boneka kecil kelinci mekanik menonton

Tanda ini terjadi sebagai akibat dari dua faktor yaitu berpikir mandiri dan ketakutan akan kehilangan rekognisi dari publik. Sesuai dengan teori dari Vries (2003), faktor berpikir mandiri terjadi ketika seseorang sebelum pensiun atau melepaskan jabatannya, ia selalu memikirkan pekerjaan. Hal ini menyebabkan fokus pikirannya tertuju hanya pada perkerjaan, setelah pensiun maka pada masa transisi pemikiran ini masih melekat sehingga terkadang merasa masih memiliki jabatan tersebut. Sedangkan untuk faktor ketakutan akan kehilangan rekognisi dari publik terjadi sebagai akibat dari rasa dihargainya ketika masih menjabat atau memiliki pekerjaan. Ketakutan ini dalam masa transisi juga masih memperlihatkan sisi berkuasa atau masih memiliki jabatan tersebut. Pada film, 
hal ini disebabkan karena sang televisi tua masih merasa bahwa dia adalah televisi yang berguna atau yang tidak terbuang dan berbeda dengan bendabenda lain yang terbuang di tempat pembuangan tersebut.

2. Tanda yang menunjukan penolakan situasi baru.

Sang Televisi tua mengusir Boneka Kelinci Mekanik

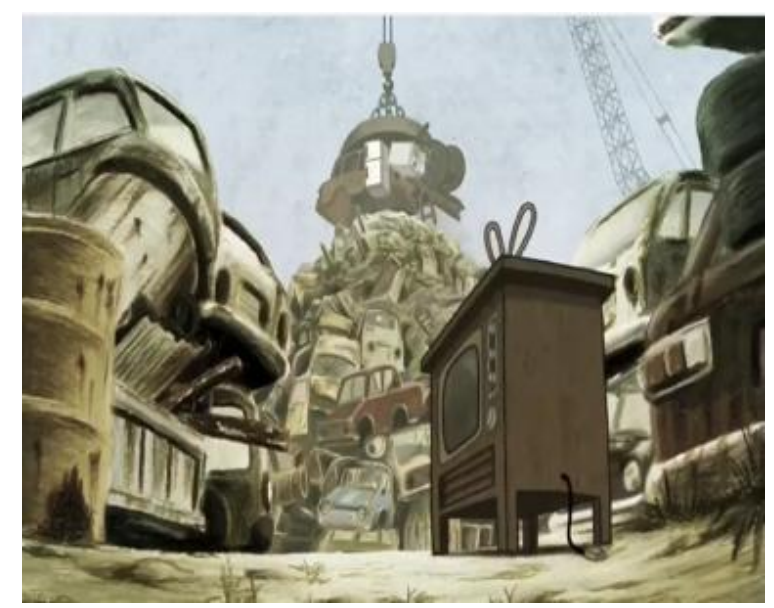

Gambar 2. Pemicu Penolakan Situasi Baru

Tanda yang menunjukan penolakan terhadap situasi yang baru, terlihat dari keinginan sang televisi tua untuk keluar dari tempat pembuangan. Hal ini disebabkan karena ia ketakutan akan ketidak bergunaan dirinya atau kematian dirinya. Hal ini dipicu ketika ia melihat magnet raksasa yang membawa rongsokan ke tempat penghancuran. Melihat hal tersebut membuat tekad untuk keluar semakin besar.

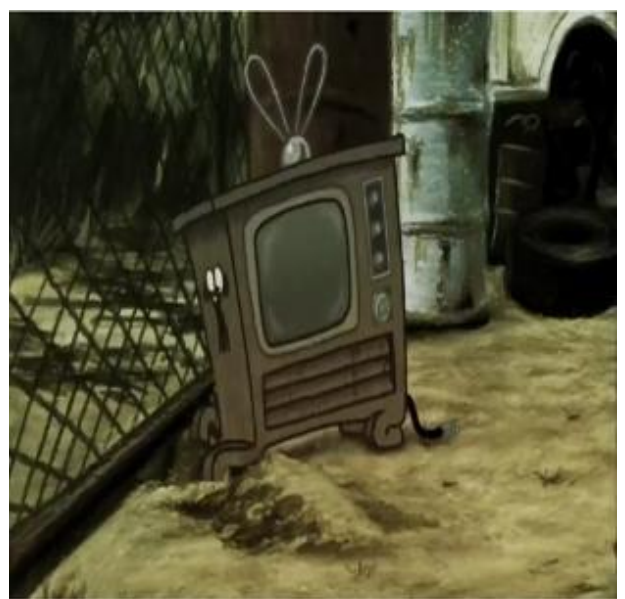

Gambar 3. Menggali Untuk Kabur

Sang televisi tua yang ketakutan tersebut mulai menggali tanah di bawah pagar untuk tempat melarikan diri. Akan tetapi usahanya tersebuta memerlukan waktu dan tenaga yang besar. Kemudian, ia berusaha untuk memanjat pagar, dan lagi-lagi usahanya ini pun sia-sia. Penolakan yang keras ini terjadi selain karena ada pemicu terhadap hal tersebut, juga terjadi karena ketidaksiap mental dari sang televisi tua terhadap posisi dan lingkungan barunya. 


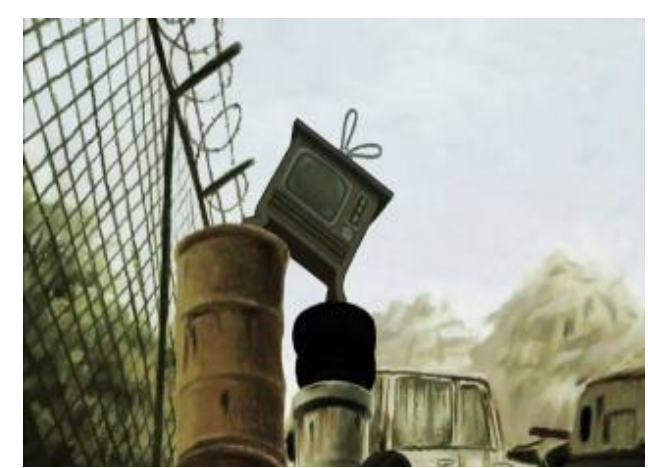

Gambar 4. Melompat Pagar Untuk Kabur

Perilaku ini disebabkan oleh faktor akan ketakutan kehilangan kontrol dan rasa dibutuhkan (Vries, 2003). Lebih lanjut, Vries (2003) mengatakan takut akan kehilangan kontrol artinya, para pensiunan atau orang yang berhenti bekerja tersebut takut kehilangan kekuatan kontrol mereka. Ketika masih bekerja, dengan kuasa mereka, mereka dapat mengontrol seseorang, jika mereka pensiun maka hal tersebut tidak lagi bisa dilakukan. Kemudian ketakutan akan kehilangan rasa dibutuhkan itu berarti mereka takut tidak ada lagi orang-orang yang membutuhkan mereka. Efek yang ditimbulkan dari kedua faktor ini adalah merasa kesepian, atau merasa sendiri (Vries, 2003). Hal itu pun yang terjadi dengan sang televisi tua. Walaupun ada boneka kelinci mekanik, ia merasa sungkan untuk meminta bantuan, atau menceritakan keinginannya. Sang televisi tua lebih senang melakukannya sendiri.

3. Tanda yang menunjukan rasa tidak percaya diri.

Bagian ini merupakan klimaks dari film Golden Time. Pemicu tanda ini lahir adalah hilangnya tabung televisi yang dimiliki oleh sang televisi tua. Pada televisi tabung, bagian tabung televisi adalah hal yang penting. Jika itu hilang, maka fungsi sebagai televisi juga hilang. Bayangkan jika sebuah televisi tidak lagi bisa berfungsi sebagai televisi, hal inilah yang dirasakan oleh tokoh utama. Kejadian ini bermula dari keinginan sang televisi tua untuk keluar dari tempat pembuangan. Ketika sang televisi tua melihat ada mobil servis elektronik masuk, ia merasa ini adalah jalan untuk keluar dari tempat pembuangan tersebut. Sehingga ia memperlihatkan kemampuanya dengan menunjukan layar televisi yang menyala. Akan tetapi, tukang servis yang melihat itu hanya melihatnya sebagai tabung yang berfungsi saja. Sehingga oleh tukang reparasi, bagian tabung itu diambil. Ketika itu terjadi maka hilang fungsi yang berharga dari sang televisi tua. Hal ini kemudian membuat sang televisi tua menjadi tidak percaya diri lagi. 


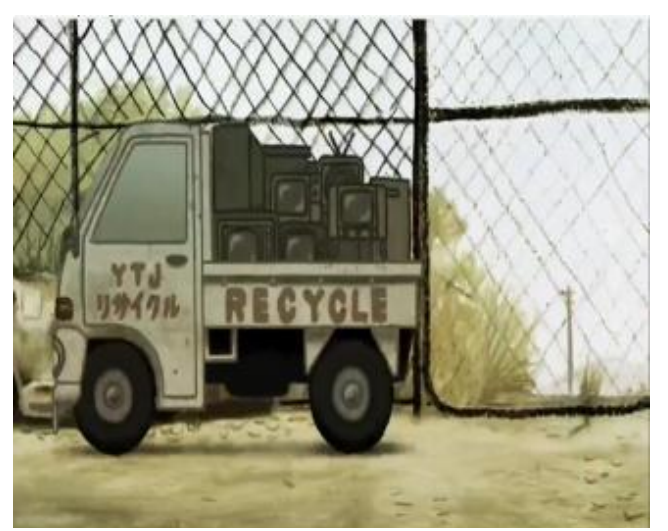

Gambar 5. Mobil Servis Elektronik

Untuk bagian ini secara metaforis dapat diibaratkan seperti berkurangnya penghasilan atau hilangnya penghasilan bagi para pensiunan atau orang yang kehilangan pekerjaan. Pada post-power syndrome, bagian finansial ini menjadi topik sentral. Perubahan dari memiliki kenyamanan finansial menjadi tidak memiliki kembali maka hal ini dapat menimbulkan efek psikologis. Hal ini sesuai dengan konsep dari Vries (2013). Pada film ini representasi itu diberikan secara metaforis melalui simbol tabung televisi. Karena bagian itu merupakan bagian penting bagi sang televisi tua. Menariknya lagi hal ini disensor dalam film, Seolah-olah mengambil tabung televisi itu merupakan perbuatan keji. Sensor tersebut berupa gambar ilutrasi dari sistem elektronik televisi, Kemudian, tanda ini diperkuat dari tanda lainnya. Tanda yang memperkuat hal tersebut adalah reaksi dari para televisi yang melihat langsung kejadian tersebut. Televisi-televisi tersebut berada di atas mobil reparasi, dan reaksinya seperti ini.

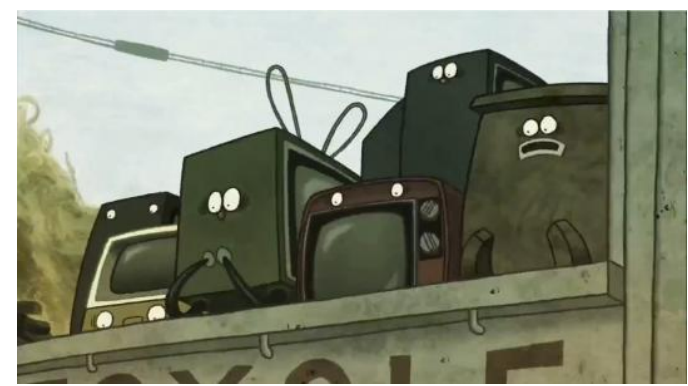

Gambar 6. Reaksi Dari Televisi Lainnya

Perubahan ini menimbulkan efek psikologis yang besar bagi sang televisi tua. la berusaha mencari pengganti tabung dalam dirinya. Berusaha memasangkan dengan papan iklan dan sebagainya. Akan tetapi hal itu tidak berefek positif bagi dirinya, justru membuat jadi lebih terpuruk.

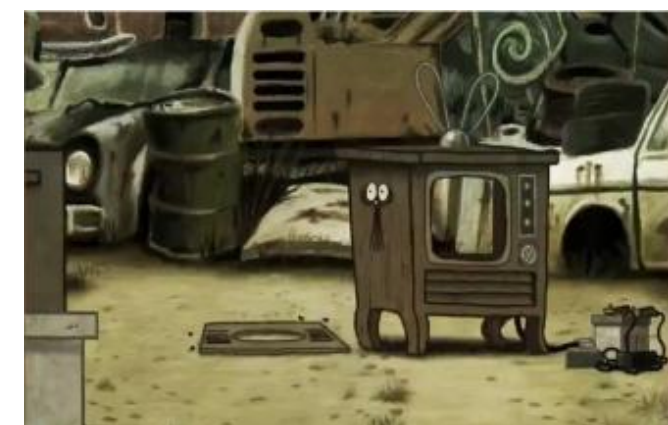

Gambar 7. Ekspresi Syok dari Tokoh Utama

Jurnal Pendidikan Bahasa Jepang | 309 
Rasa tidak percaya diri itu pun berubah menjadi depresi. Setelah tahu ia tidak akan berguna lagi maka dia berniat untuk bunuh diri. Sang televisi tua itu pun berniat ke bukit tumpukan barang rongsokan agar bisa ditarik oleh magnet dan dibawa ke tempat penghancuran sampah. Melihat hal tersebut boneka kelinci mekanik berusaha untuk menyadarkan sang televisi tua. Pada saat itu sang televisi tua tidak mengindahkan boneka kelinci mekanik, dan tetap pada pendiriannya. Hingga magnet pengangkut sampah tersebut gagal mengangkat sang televisi tua, dan hanya mencabut antenanya saja.

4. Tanda yang menunjukan optimisme.

Tanda ini ditunjukan secara terpisah antara pembanding satu dan dua. Sebelum adegan sang televisi tua kehilangan tabungnya, terdapat tanda yang menunjukan seberapa rindunya sang televisi tua dengan kehidupan lamanya. Dalam adegan tersebut diperlihatkan satu keluarga kecil yang memiliki dua anak laki-laki sedang menonton dirinya.

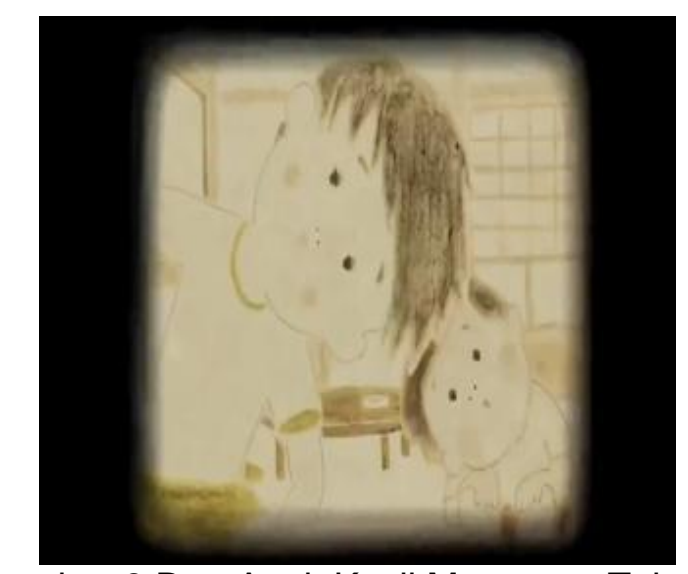

Gambar 8.Dua Anak Kecil Menonton Televisi

Dari sudut pandang visual yang diberikan seperti pada gambar 4.12 terlihat raut wajah penasaran dan antusias dari kedua anak tersebut. Kenangan itu begitu melekat bagi sang televisi tua.

Seperti yang dikatakan oleh Elia (2003 dalam Suyanto, 2016), terdapat ketidak stabilan psikis yang terjadi bagi orang yang mengalami post-power syndrom. Lalu, ketika sang televisi tua tidak berhasil melakukan bunuh diri karena dihalangi oleh boneka kelinci mekanik, ia merasa bahwa sudah tidak memiliki harapan lagi. Sehingga yang tersisa hanya kenangan itu saja. Tetapi, klimaks dari film ini bukanlah menjadi adegan terakhir dalam film. Film ini menempatkan akhir film dengan adegan anti klimaks. Terlihat dari setelah kejadian bunuh diri yang gagal itu, keesokan paginya, ketika sang televisi tua tertidur ia dibawa ke sebuah rumah, dan dijadikan sebagai kandang ayam.

Pada awalnya sang televisi tua tidak nyaman dengan fungsi barunya tersebut. Tetapi, setelah ia melihat ada dua anak kecil yang memperhatikannya, dan menunggu telur ayam keluar dari tubuhnya, ia kembali terkenang dengan rasa bahagia di masa lalunya. Sang tokoh utama kembali merasa optimis dengan kehidupan barunya, ia merasa berfungsi kembali. 


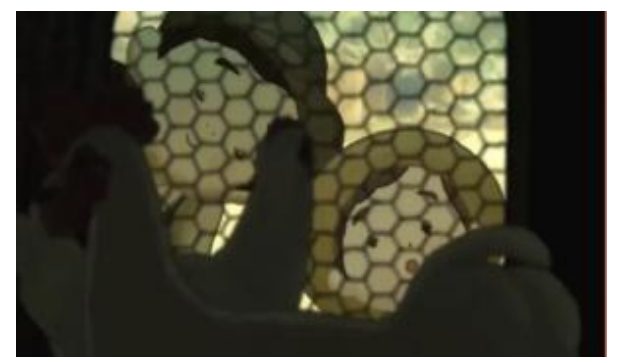

Gambar 9.Dua Anak Kecil Melihat Ayam dikandang

Secara denotatif, akhir dari film ini menunjukan sebuah solusi yang ingin diberikan oleh Inaba (selaku animator), yaitu sikap optimisme itu perlu untuk mengatasi sebuah masa transisi keadaan. Hal ini juga sesuai dengan penelitian Yunian (2013) yang memperlihatkan post-power syndrome memberikan pengaruh negatif bagi optimisme para pensiunan. Padahal, optimisme diperlukan untuk memberikan keyakinan pada diri, bahwa masa pensiun bukan berarti akhir dari segalanya.

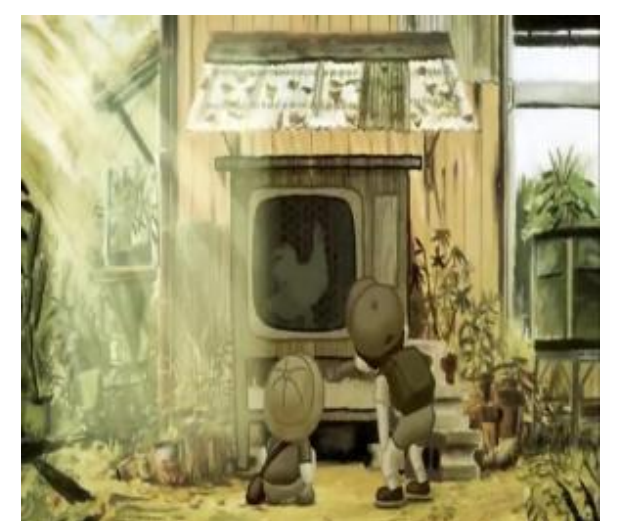

Gambar 10.Tokoh utama bahagia dengan fungsi baru

Kemudian lapisan kedua (signifikansi tingkat dua) atau makna konotatif pada tanda-tanda yang telah ditemukan di lapisan pertama (makna denotasi). Sehingga mitos dari dari film ini dapat tebentuk. Mitos tersebut akan memperlihatkan representasi tanda visual pada film Golden Time (2014) ini.

Analisa dimulai dengan menjawab pertanyaan, "kenapa menggunakan televisi sebagai simbol yang menunjukan post-power syndrome di film Golden Time (2014)?". Pada tahun1935 televisi mulai diproduksi masal oleh sharp . Kemudian, pada bulan Januari 1953, televisi dengan model TV3-14T mulai dipasarkan di Jepang. Pada masa itu, harga model tersebut adalah 175.000 yen. Pemasaran ini berkembang dengan baik karena pada bulan Februari 1953, NHK mulai siaran selama empat sehari. Sehingga pada masa itu total terdapat 866 rumah tangga yang memiliki dan dapat menonton televisi di Jepang .

Selain Sharp pada masa yang sama terdapat perusahaan elektronik lainnya juga yang turut mengembangkan televisi atau pun transistor televisi di Jepang. kemudian pada masa yangsama terdapat perusahaan elektronik lain juga yang turut mengembangkan televisi yaitu panasonic. Panasonic mulai mengembangkan televisi pada tahun 1935. Pada masa itu, Kenjiro Takayanagi di sekolah teknik vokasional Hamamatsu mengembangkan sistem fungsi ikonoskop (tabung kamera yang dapat memperlihatkan gambar bergerak). Penelitian itu dilanjutkan Panasonic di akhir tahun 1935. Pengembangan berlanjut hingga tahun 1938, Panasonic mengeluarkan prototipe satu set televisi 12 inchi. Prototipe tersebut pada bulan mei 1939 telah berhasil menerima transmisi siaran 
dari Tokyo Broadcast Center. Pengembangan ini dilakukan karena direncanakan akan ada Olimpiade pada tahun 1940, akan tetapi sayangnya karena terdapat perang maka even internasional tersebut batal diselenggarakan. Tetapi setelah itu perkembangan televisi di Panasonic terus dikembangkan

Kemudian terdapat perusahaan sony. Sony membuat prototipe televisi mereka yang pertama kali. Melihat tentang tinjauan tentang sejarah perusahaan televisi di Jepang, belum menunjukkan bukti kuat alasan pemelihan televisi sebagai tokoh utama dalma film Golden Time (2014). Menurut laporan berita NHK, siaran TV berwarna pertama di Jepang dimulai pada tanggal 10 September 1960. Jepang adalah negara ketiga di dunia yang mengadopsi sistem NTSC setelah Amerika Serikat dan Kuba. Komite Sistem Televisi Nasional AS (NTSC), standarnya memiliki 525 jalur pemindaian.

Salah satu karakteristik paling signifikan dari sistem ini adalah kemampuan untuk membuat program televisi berwarna dapat dilihat di televisi hitam-putih. Pada masa itu, banyak stasiun memiliki sumber daya dan fasilitas yang tidak memadai untuk penyiaran warna, sehingga program penyiaran televisi berwarna kebanyakan terdiri dari film-film asing, siaran olahraga estafet, dan program pendidikan pendek. Pada saat itu, biaya televisi berwarna 21 inci sekitar 500.000 yen. Hal ini di luar kemampuan kebanyakan orang, dan hanya 1.200 unit telah terjual ketika penyiaran TV berwarna dimulai.

Namun hal ini berubah, perlahan penyiaran televisi berwarna mulai meningkat karena terdapat satu momentum di tahun 1964. Perusahaan penyiaran televisi di seluruh Jepang termasuk NHK menggabungkan upaya mereka pada produksi siaran TV Olimpiade Tokyo pada Oktober 1964. Mereka mengembangkan peralatan televisi di dalam negeri, termasuk tabung pengambilan gambar dan peralatan untuk siaran relay satelit. Siaran langsung Olimpiade menggunakan satelit geostasioner Syncom 3 dan merupakan siaran satelit pertama dalam sejarah. Satelit ini awalnya dirancang untuk penggunaan sirkuit telepon dan tidak memiliki kapasitas yang memadai untuk mengirimkan sinyal televisi, tetapi aplikasi teknologi kompresi baru memiliki uji coba yang berhasil hanya tiga hari sebelum upacara pembukaan

Dengan ini menjadi jelas alasan pemilihan tokoh utama pada film Golden Time (2014) menggunakan simbol televisi. Ditambah lagi, NHK menyebutkan TV Olimpiade 1964 tersebut mencatatkan rerata penonton sebesar $95 \%$. Sehingga Jepang bisa memperlihatkan keunggulan teknologinya pada masa tersebut.

Kemudian, representasi ini masih perlu dikaji lagi. Jika memang televisi mengambil momentum kejayaan Jepang di tahun 1964, lalu mengapa seting film berada di 1980-an? Dalam kehidupan nyata, apa yang menjadi representasi dari tokoh utama tersebut? Jepang secara ekonomi pernah mengalami masa nyaman dari 1950-an hingga akhir 1980-an. Masa nyaman ini kemudian berubah begitu memasuki tahun 1990-an. Maka dari pemaparan ini diketahui bahwa, Inaba mengambil analogi post-power syndrome pada film lebih menunjukan bentuk komunikasi metaforis yang menunjukan transisi dari posisi ekonomi Jepang yang meningkat hingga turun dan stagnan. Analogi itu juga berperan dalam penyampaian pesan bahwa, hingga kini Jepang telah bertranformasi secara ekonomi ke arah yang lebih optimistik (seperti tanda terakhir yang ditemukan). Menariknya lagi melalui analisis ini, dapat melihat bagaimana Jepang mengembangkan teknologi, dan membangun ekonomi dengan mengambil even internasional. Olimpiade tahun 1940 membuat Jepang mengembangkan produk televisi, olimpiade 1964 membuat Jepang mengembangkan sistem penyiaran modern pertama, dan kemungkinan olimpiade 2020 membuat Jepang mampu mengembangkan industri dan perekonomiannya ke aras yang positif. Film ini 
juga memperlihatkan bahwa transisi tersebut harus dihadapi secara fleksibel, seperti sang televisi tua yang mengubah fungsinya dari televisi ke kandang ayam. Mungkin berbeda tetapi tetap memiliki guna. Begitu pun dengan perekonomian yang Jepang yang direpresentasikan pada film ini, mungkin Jepang tidak bisa kembali ke posisi di tahun 1950-an hingga 1980-an, akan tetapi Jepang masih bisa memiliki peran bagi dunia dengan posisi yang berbeda. Selama itu tetap memiliki guna bagi dunia global.

Otsubo (2007), menjelaskan selain kurangnya persaingan internasional, laju pertumbuhan ekonomi yang lebih lambat setelah akhir proses catch-up membatasi ruang untuk kompetisi pasar di sektor-sektor non-manufaktur (nontradable). Sistem pasar tradisional Jepang dan peraturan publik terus membatasi persaingan dan sektor kredit yang jatuh tempo atau menurun justru yang dilindungi oleh aturan ini. Sehingga kurangnya kompetisi menyebabkan produktivitas yang lebih rendah di sektor-sektor ini, yang pada gilirannya menimbulkan biaya tinggi bagi konsumen dan industri manufaktur yang berkembang. Karena globalisasi, kegiatan ekonomi dan perkembangan pesat teknologi informasi, maka ekonomi Jepang telah memasuki era ekonomi pengetahuan yang beragam. Di sini, bahkan daya saing dari sektor-sektor yang tidak dapat diperdagangkan ditentukan oleh ide-ide kreatif dan perilaku inovatif dalam pengambilan risiko keuangan.

Permasalahan-permasalahan tersebut telah menjadi lubang-lubang kecil pada gelembung ekonomi Jepang. Sehingga puncaknya terjadi pada tahun 1990-an. Tingkat dua digit ekspansi agregat moneter memicu inflasi pasar aset. Harga tanah naik rata-rata 50\% nasional selama paruh kedua 1980-an. Di Tokyo dan kawasan bisnis metropolitan lainnya, harga tanah bahkan tiga kali lipat,

Memuncak pada awal 1991. Harga saham dalam hal rata-rata Nikkei naik empat kali lipat ke nilai puncak pada akhir 1989. Ketika Jepang menjadi semakin optimis mengenai masa depan ekonomi, dana besar digelontorkan proyek bisnis dalam dan luar negeri. Penumpukan 'kelebihan' yang dihasilkan, seperti kelebihan kapasitas, kelebihan pekerjaan, kelebihan kewajiban dan kelebihan pasokan pinjaman, mengharuskan proses penyesuaian stok yang panjang begitu ekonomi gelembung pecah di awal 1990-an (Otsubo, 2007).

Dari pemaparan tentang ekonomi Jepang oleh Otsubo Maka dari pemaparan ini diketahui bahwa, Inaba mengambil analogi post-power syndrome pada film lebih menunjukan bentuk komunikasi metaforis yang menunjukan transisi dari posisi ekonomi Jepang yang meningkat hingga turun dan stagnan. Analogi itu juga berperan dalam penyampaian pesan bahwa, hingga kini Jepang telah bertranformasi secara ekonomi ke arah yang lebih optimistik (seperti tanda terakhir yang ditemukan). Menariknya lagi melalui analisis ini, dapat melihat bagaimana Jepang mengembangkan teknologi, dan membangun ekonomi dengan mengambil even internasional. . Film ini juga memperlihatkan bahwa transisi tersebut harus dihadapi secara fleksibel, seperti sang televisi tua yang mengubah fungsinya dari televisi ke kandang ayam. Mungkin berbeda tetapi tetap memiliki guna. Begitu pun dengan perekonomian yang Jepang yang direpresentasikan pada film ini, mungkin Jepang tidak bisa kembali ke posisi di tahun 1950-an hingga 1980-an, akan tetapi Jepang masih bisa memiliki peran bagi dunia dengan posisi yang berbeda. Selama itu tetap memiliki guna bagi dunia global.

Jadi kembali ke rumusan masalah, bagaimana representasi post-power syndrome pada film Golden Time 2014 karya Takuya Inaba? Dilihat dari theori Barthes maka representasi post-power syndrome pada film, menunjuk kepada transisi perekonomian Jepang dari tahun 1950-an hingga 1980-an. Transisi ini 
secara mitos digunakan untuk menunjukan optimisme Jepang dalam mentransformasi posisinya di dunia, baik itu dalam bidang industri, politik, maupun ekonomi.

\section{SIMPULAN DAN SARAN}

Ada empat tanda visual yang bermakna denotasi dalam penelitian ini yaitu, tanda yang menunjukkan sikap berkuasa, tanda yang menunjukkan penolakan situasi baru, tanda yang menunjukkan rasa tidak percaya diri, dan tanda yang menunjukkan optimisme dalam film Golden Time (2014) karya Takuya Inaba. Dari theori Barthes dapat dilihat bahwa representasi post-power syndrome pada film, Golden Time (2014) karya Takuya Inaba menunjuk kepada transisi perekonomian Jepang dari tahun 1950-an hingga 1980-an. Transisi ini secara mitos digunakan untuk menunjukan optimisme Jepang dalam mentransformasi posisinya di dunia, baik itu dalam bidang industri, politik, maupun ekonomi.

Saran untuk penelitian selanjutnya diharapkan agar lebih intens dalam mengambil data yang ada. Diharapkan bisa lebih baik dari penelitian ini.

\section{DAFTAR PUSTAKA}

Miles, Matthew, B., Huberman, A., Michael., Saldana, Johnny. 1994. Qualitative Data Analysis: A Method Sourcebook 3rd edition.SAGE Publication

Redana, Made. 2006. Panduan Praktis Karya Ilmiah dan Proposal Riset. Denpasar .

Suyanto, Abdul Rahman. 2016."Post Power Syndrome dan Perubahan Prilaku Sosial Pensiun Guru “. Jurnal IImiah Psikologi. Volume 3. Nomer 1(hal 77-79)

Otsubo, Shigeru, T., 2007. The Japanese Economy: Development Japanese/Asia Style. Diakses pada tanggal 4 Juli 2019. Terdapat pada alamat berikut https://www.gsid.nagoya-.ac.jp/sotsubo/Postwar_Development_of_the_ Japanese\%20Economy(Otsubo_NagoyaU).pdf 